\title{
Formulation and Physical Characterization of Black Soybean (Glycine Max L.) Variety of Detam II Tablets with Dry Granulation Method
}

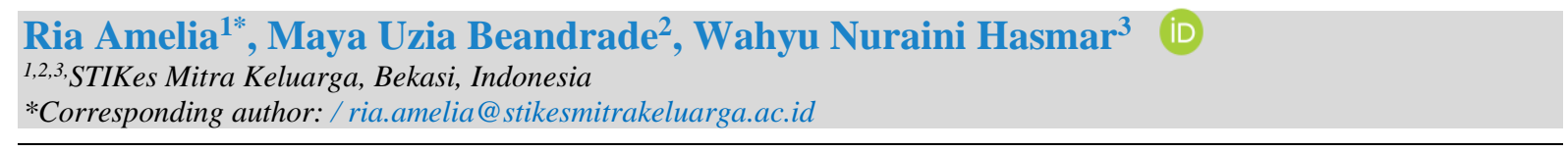

\section{Abstrak}

Tingginya kandungan protein pada kedelai berbanding lurus dengan kadar senyawa flavonoid. Formulasi pembuatan tablet dari bubuk kedelai hitam Detam II sulit ditentukan karena kandungannya yang membuat sulit untuk mendapatkan kekerasan tablet yang optimal. Penelitian ini bertujuan untuk mendapatkan formulasi tablet kedelai hitam varietas detam II. Penelitian dilaksanakan pada bulan Februari sampai Oktober 2020 di Laboratorium Teknologi Farmasi STIKes Mitra Keluarga. Pembuatan tablet kedelai hitam (Glycine max L.) varietas detam II dengan metode slugging. Tablet kedelai hitam Detam II (Glycine max L.) dibuat menjadi 5 formula dengan kandungan $250 \mathrm{mg}$ bubuk kedelai hitam (Glycine max L.) varietas detam II pada setiap formula. Variabel yang membedakan adalah senyawa eksipien tablet pada masing-masing formula yaitu PVP K30, gelatin, dan amilum maydis sebagai bahan pengisi-pengikat. Kami menggunakan tipe eksperimen trial and error untuk membuat setiap formula. Evaluasi granul tablet kedelai hitam (Glycine max L.) varietas detam II dengan pengujian kadar air, kompresibilitas, waktu alir, sudut istirahat dan evaluasi tablet dengan pengujian organoleptik, berat, kekerasan, kerapuhan dan waktu hancur. Hasil penelitian menunjukkan bahwa formula 3, 4 dan 5 merupakan formulasi yang direkomendasikan untuk pembuatan tablet kedelai hitam (Glycine max L.) varietas detam II meskipun semua formula ( F1-F5) berada di bawah persyaratan nilai kerapuhan karena beberapa faktor. . Eksipien gelatin dan PVP K30 untuk pembuatan tablet kedelai hitam (Glycine max L.) varietas detam II merupakan pilihan terbaik sebagai pengisipengikat tablet.

Kata Kunci: Glycine max L., Detam II, Formula dan Eksipien Tablet

\section{Abstract}

The high protein content in soybeans is directly proportional to the levels of flavonoid compounds. The formulation for making tablets from Detam II black soybean powder is difficult to determine because of its content which makes it difficult to obtain optimal tablet hardness. This study aims to obtain a tablet formulation of black soybean detam II varieties. The research was conducted from February to October 2020 at the Pharmaceutical Technology Laboratory STIKes Mitra Keluarga. Preparation of black soybean (Glycine max L.) tablet of detam II variety by slugging method. Detam II black soybean tablets (Glycine max L.) were made into 5 formulas with $250 \mathrm{mg}$ black soybean powder (Glycine max L.) content of detam II varieties in each formula. The differentiated variable is the tablet excipient compound in each formula are PVP K30, gelatin, and amylum maydis as filler-binder. We use trial and error experimental type for make each formula. Evaluation of black soybean (Glycine max L.) tablet granules of detam II variety by testing water content,compressibility, flow time, angle of rest and tablet evaluation by testing organoleptic, weight, hardness, brittleness and disintegration time. The results showed that a formula 3,4 and 5 are the recommended formulations for the manufacture of black soybean tablets (Glycine max L.) detam II varieties even though all formula ( F1-F5) were below the friability value requirements due to several factors. Gelatin excipient and PVP K30 for the manufacture of black soybean tablets (Glycine max L.) detam II varieties are the best choices as tablet filler-binder..

Keywords: Glycine max L., Detam II, Tablet Formula and Excipient

\section{Introduction}

Black soybean (Glycine max L.) detam II varieties are widely grown and consumed throughout the world, especially in Asian countries because they contain many benefits (Lee K.J., et al., 2020). These soybeans are black due to the accumulation of anthocyanins in the epidermal palisade layer that coats the soybean seeds (Kim J.M., et al., 2008). Other

$\begin{array}{ll}\text { History: } & \\ \text { Received } & : 31 \text { Maret } 2021 \\ \text { Revised } & : 06 \text { April } 2021 \\ \text { Accepted } & : 15 \text { April } 2021 \\ \text { Published } & : 25 \text { April } 2021\end{array}$

Published : 25 April 2021

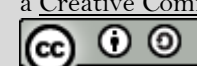


phytochemical content in black soybeans, namely isoflavones, sterols, phytic acid, saponins, and phenolics, are effective for human health and prevent various chronic diseases (Zhang R.F., et al., 2011). Another study states that black soybeans have the largest antioxidant content among other varieties due to the presence of phenolic compounds, especially anthocyanin compounds in the seed layer (M. Slavin,. et al., 2009). Black soybeans contain high protein (32-43.6\%), carbohydrates (31.7-31.85\%), fat (15.5-24.7\%), water $(5.6-11.5 \%)$, minerals (calcium, phosphorus, magnesium, potassium, sodium, selenium, etc.), as well as vitamin E, B complex, etc. (Fetriyuna, 2015). Fat content, especially unsaturated fatty acids, is around $86 \%$, especially linoleic acid (6.48-11.6\%), linolenic acid (0.72-2.16\%) and oleic acid (3.15-8.82\%) . The health benefits of black soybeans include neuroprotective, antiobesity, anti-cancer, antioxidant, anti-hyperlipidemic, anti-inflammatory, cardioprotective, anti-diabetes (Ganesan, K and B. Xu., 2017).

Granulation is a process in which fine powder particles are made into larger particles or so-called granules. One of the granulation methods is dry granulation. This method is considered simple and saves more time and money. One of the processes that occurs in dry granulation is called the slugging process, in which the powder is pressed into large, homogeneous tablets (called slugs), then the first pressed tablets are crushed using a certain size to form larger granules. This method is also usually used for powders with poor flow properties or for materials that are difficult to compress ( Jannat E., et al., 2016). Black soybeans are natural compounds that contain high water and oil content so that they can affect the flow properties of the material to be bad and difficult to compress into tablets. The dry granulation method is suitable for materials which are hydrophobic and contain oil (Muralidhar P., et al., 2016). Good flow properties are the main requirements for a material to flow to the printing press for compression. Previous research has made tablets with various concentrations of silicon dioxide and magnesium stearate with PVP K30 as a binder but has not obtained tabet hardness according to the requirements (Yulia R., et al., 2018). This study aims to make a Detam II tablet formula with dry granulation and uses a variety concentration of binders and fillers such as PVP K30, amylum maydis, and gelatin.

\section{Materials and Methods}

\section{Preparation of Black soybean powder (Glycine max L.) detam II variety}

Black soybean (Glycine Max L.) detam II varieties were blended and then sieved using a sieve number 30. The black soybean powder is then stored in a dry place and protected from light (Yulia R., et al., 2018). Black soybean powder and other ingredients such as PVP K30, gelatin, and starch maydis were weighed according to the formula then stirred manually for 15 minutes. This mixture is then compressed using a printing machine and then crushed again with a sieve number 12. Black soybean tablet (Glycine Max L.) preparation of detam II varieties. The slugging granules were then mixed manually with sodium starch glycolate, talcum, and magnesium stearate for 5 minutes. The physical properties of these granules are evaluated before being compressed into tablets. The resulting tablet size has a diameter of 13 $\mathrm{mm}$ with a final weight of $700 \mathrm{mg}$. Furthermore, the physical test of the black soybean tablet variety Detam II was carried out (Yulia R., et al., 2018). Evaluation of black soybean granule (Glycine Max L.) of detam II variety. The water content of black soybean powder and granules of Detam II variety was tested using a moisture content device with a sample weight of 1.0 gram and a heating temperature of $105{ }^{\circ} \mathrm{C}$. This test is carried out by inserting the powder sample into a measuring cup until the volume reaches $100 \mathrm{~mL}$ then the sample weight is also weighed. The initial volume and final volume of the determination are calculated to obtain the values of Bulk Density, Tapped Density, Carr's Index, and Hausner Ratio.

A total of 100 grams of granules are put into a funnel with a diameter of $10 \mathrm{~mm}, 15$ $\mathrm{mm}$, and $25 \mathrm{~mm}$. Flow time is recorded using a stopwatch. A good sample flow time of 100 
grams of sample should be able to flow through a $10 \mathrm{~mm}$ funnel in less than 11 seconds (Yulia R., et al., 2018). The angle of repose is determined using a special AoR funnel on the test instrument. 100 grams of granules are inserted into the funnel. A good value for angle of repose is 25-40 (Yulia R., et al., 2018). The physical evaluation of detam II black soybean tablets included tablet form, tablet color, and tablet odor (Prasanthi S., et al., 2015). Twenty tablets were weighed thoroughly and their average weight was calculated. Weighed one tablet at a time, compared to the average weight of tablets. The requirement for tablet weight uniformity that is set for tablet weights of more than $300 \mathrm{mg}$ is not more than 2 tablets whose weight deviates from the average weight of more than $5 \%$ and none of the tablets whose weight deviates from the average weight of more than $10 \%$ (Kusuma, D and E.D. Apriliani, 2018). The tool used is the Erweka hardness tester. One tablet is placed in the middle perpendicular to the instrument, then the tool is pressed and the tablet hardness value is seen. Generally, tablet hardness ranges from 4 - 8 kP (Rabbani, F., et al., 2017, Setyawan D., et al., 2020).

The tablets are cleaned first and then weighed. 10 Detam II tablets were weighed and then all of them were put into the Erweka fragility test kit. The tool is run for 4 minutes at a speed of $25 \mathrm{rpm}$. After finishing the tablet is cleaned of dust and then weighed again carefully. The percentage of weight loss of tablets is calculated with terms $<1 \%$. If there is a tablet that breaks during the test, it does not meet the tablet fragility test requirements (Rabbani, F., et al.2017). The disintegration time of the tablets using Erweka to 6 tablets of detam II. One tablet insert to each tube of the test equipment basket, put a disc on top of the tablet then run the instrument. Water with a temperature of $37 \pm 2^{\circ} \mathrm{C}$ is used as the medium. The disintegration time tester is run and time by which all the tablets are able to pass through the basket on the device is calculated. The time taken to crush the tablet is no more than 15 minutes for the uncoated tablet (Kusuma, D and E.D. Apriliani, 2018).

\section{Results and Discussion}

Detam II variety of black soybean powder (Glycine max L.) has a slightly sweet taste with a distinctive soy odor. The results of the water content of the black soybean granule of Detam II variety before being pressed can be seen in Table 1. The results of the water content of the granules in the study fell into this theoretical value range.

Table 1. Granule water content (\%MC) (Source: Primary Data)

\begin{tabular}{ll}
\hline Formula & \% MC \pm SD \\
\hline F1 & $4.97 \pm 0.04$ \\
F2 & $4.43 \pm 0.01$ \\
F3 & $4.88 \pm 0.02$ \\
F4 & $4.90 \pm 0.01$ \\
F5 & $4.98 \pm 0.03$ \\
\hline
\end{tabular}

The results of Carr's index and Haussner's ratio of black soybean granule for detam II variation can be seen in Table 2 .

Table 2. Results of Carr's Index and Hausner Ratio of black soybean granule (Glycine max L.) detam II variety (Source: Primary Data)

\begin{tabular}{rlll}
\hline Formula & Carr's Indeks (\%) & Hausner Ratio & Characteristics granule \\
\hline F1 & $28,6 \pm 0,002$ & $1,40 \pm 0,005$ & Poor \\
F2 & $28,6 \pm 0,003$ & $1,40 \pm 0,006$ & Poor \\
\hline
\end{tabular}




\begin{tabular}{rlll}
\hline Formula & Carr's Indeks $(\%)$ & Hausner Ratio & Characteristics granule \\
\hline F3 & $21,1 \pm 0,005$ & $1,27 \pm 0,008$ & Passable \\
F4 & $24,8 \pm 0,001$ & $1,33 \pm 0,002$ & Passable \\
F5 & $23,7 \pm 0,004$ & $1,31 \pm 0,006$ & Passable \\
\hline
\end{tabular}

Flow time and angle of repose of the granule.

Granule flow time and angle of repose of black soybean granule of detam II variety can be seen in Table 3 and Table 4.

Table 3. Results a time of flow of black soybean granule (Glycine max L.) detam II variety (Source: Primary Data)

\begin{tabular}{lll}
\hline Formula & Time of $\mathbf{F l o w}(\mathbf{s} / \mathbf{1 0 0} \mathbf{g})$ & Characteristics granul \\
\hline F1 & $16,07 \pm 0,21$ & Very Cohesive \\
F2 & $16,73 \pm 0,25$ & Very Cohesive \\
F3 & $14,7 \pm 0,31$ & Cohesive \\
F4 & $14,9 \pm 0,50$ & Cohesive \\
F5 & $15,6 \pm 0,53$ & Cohesive \\
\hline
\end{tabular}

Table 4. Result of angle of repose of black soybean granule (Glycine max L.) detam II variety (Source: Primary Data)

\begin{tabular}{lll}
\hline Formula & Angle of repose & Characteristics granul \\
\hline F1 & $47,6 \pm 0,12$ & Poor \\
F2 & $50,30 \pm 0,20$ & Poor \\
F3 & $44,3 \pm 0,15$ & Passable-may hang up \\
F4 & $44,9 \pm 0,47$ & Passable-may hang up \\
F5 & $45,6 \pm 0,64$ & Passable-may hang up \\
\hline
\end{tabular}

\section{Evaluation of tablets}

Organoleptic tablets

The organoleptic results of detam II black soybean tablets, namely round, yellowish white tablets with blackish spots can be seen in Figure 1. The smell of black soybean tablets has a distinctive smell of soybeans, has a slightly sweet taste.

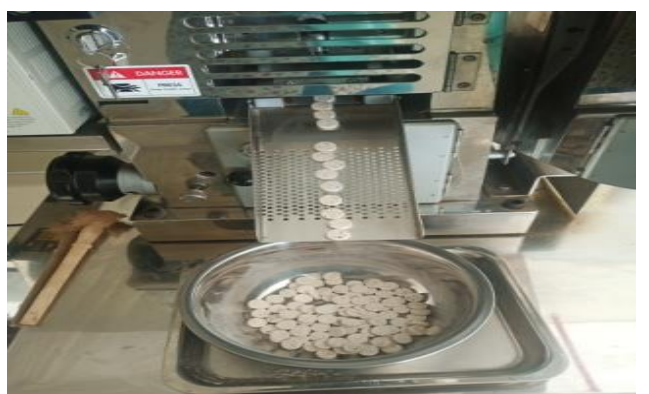

Figure 1. The result of black soybean tablets (Glycine max L.) variety detam II lugging method (Source: Primary Data)

\section{Uniformity of tablet weight}

The results of the weight uniformity of black soybeans can be seen in Table 5 . 
Table 5. Data on the weight uniformity of black soybean tablets (Source: Primary Data)

\begin{tabular}{|c|c|c|c|c|}
\hline Formula & $\begin{array}{l}\text { Average of Mass } \\
\text { Tablet (mg) }\end{array}$ & $\begin{array}{l}\text { Total tablet } \\
\text { deviates }(>\mathbf{5 \%} \text { of } \\
\text { average tablet }\end{array}$ & $\begin{array}{l}\text { Total tablet deviates } \\
\text { (>10\% of average } \\
\text { tablet weight) }\end{array}$ & Conclusion \\
\hline F1 & $651,85 \pm 26,88$ & 4 & 0 & not eligible \\
\hline $\mathrm{F} 2$ & $632,95 \pm 31,63$ & 6 & 1 & not eligible \\
\hline F3 & $679,45 \pm 10,57$ & 0 & 0 & accept \\
\hline $\mathrm{F} 4$ & $690,85 \pm 13,82$ & 0 & 0 & accept \\
\hline F5 & $699,20 \pm 13,79$ & 0 & 0 & accept \\
\hline
\end{tabular}

\section{Hardness and brittleness of tablets}

The data on the hardness and brittleness of the black soybean tablet varieties Detam II can be seen in table 6 .

Table 6. The hardness of black soybean tablet (Glycine max L.) detam II variety (Source: Primary Data)

\begin{tabular}{rlll}
\hline Formula & Hardness $(\mathbf{K p})$ & Fragility $(\%)$ & Conclusion \\
\hline F1 & $2.78 \pm 0.24$ & $6.74 \pm 0.53$ & not eligible \\
F2 & NA & NA & not eligible \\
F3 & $3.94 \pm 0.10$ & $2.13 \pm 0.08$ & not eligible \\
F4 & NA & NA & not eligible \\
F5 & NA & NA & not eligible \\
\hline
\end{tabular}

NA: Data Not Available

\section{Time crushed tablet}

Data on the disintegration time of black soybean tablets can be seen in Table 8 .

Table 7. Time crushed of black soybean tablet (Glycine max L.) detam II variety (Source: Primary Data)

\begin{tabular}{rll}
\hline Formula & Time crushed tablet (minute) & Conclusion \\
\hline F1 & $1.42 \pm 0.01$ & qualify \\
F2 & $1.33 \pm 0.02$ & qualify \\
F3 & $2.42 \pm 0.02$ & qualify \\
F4 & $1.50 \pm 0.03$ & qualify \\
F5 & $1.51 \pm 0.01$ & qualify \\
\hline
\end{tabular}

\section{Discussions}

The colour powder is Pale yellow with black spots originating from the ground color of the black soybean which has been mashed (Figure 1 and Figure 2). This black pigmentation is due to the anthocyanon content in the outer epidermis layer of black soybeans. Detam II variety of black soybean powder (Glycine $\max$ L.) has a slightly sweet taste with a distinctive soy odor. Other anthocyanins that have been identified in black soybeans are cyaniding-3glucoside, delphinidin-3-glucoside, and pelargonidin-3-glucoside (Choung, M.G., et al., 2001). The benefits of black soybeans as an antioxidant are obtained mostly in the outer shell which can prevent various diseases such as anti-diabetes, anticancer, anti-inflammatory, 
cardioprotective, osteoprotective, neuroprotective, anti-hypertensive, anti-cholesterol, antibacterial, and anti-viral (Xu, B and S.K.C. Chang, 2008).

The water content in Detam II black soybean powder was $5.77 \pm 0.04 \%$ (Table 2). This is in accordance with the theory that the water content of detam II black soybean is between 5.6-11.5\% (Ganesan, $\mathrm{K}$ and B. Xu., 2017). A good water content of granules prior to compression is 3-5\% (Hadisoewignyo,L. and A. Fudholi, 2013).

The compressibility results of granules can be assessed based on the results of the Hausner Ratio and Carr's Index (Kusumo, N.N. and S.R. Mita, 2018). Hausner ratio is the ratio between tapped density and bulk density and is an index of friction between cohesive powders, while Carr's index is a compressibility index in the form of a measure of the porosity of powders for compression. Carr's index is determined from tapped density and bulk density (Hamsinah and Ririn, 2020). Based on the data in Table 3, only formulas 3-5 which have characteristics can be compressed into tablets. The results of research conducted by Yulia et al., 2018 showed that the compressibility percentage did not meet good standard requirements, possibly due to the small particles of granule formula unable to fill the porosity between particles to become more compressed.

Granule flow time is an indication of the ease of flow of a granule when it is pressed into a tablet (Rori, W.M. and S.Sudewi, 2016). The standard value of granule flow time at a funnel diameter of $10 \mathrm{~mm}$ (Shah, R.B., et al., 2008). Angle of repose is a horizontal angle where the granules will form a perpendicular angle when stacked and can provide a good indication of the flow of granule powder (Elisabeth, V., et al., 2018). Based on the research results Table 4, the F1 and F2 formulas provide flow properties that are not as good as the F3F5 formula. This is because the F3-F5 formula uses a filler excipient in the form of gelatin. Gelatin excipient can be used as a binder in direct compression method, although it is more effective if gelatin is used for binder solution in wet granulation (Hadisoewignyo L., et al., 2016). In addition, gelatin has the characteristics of a large particle size powder and a heavy density when compared to other excipients so that it can improve the flow properties of black soybean granules (Rowe, R.C., et al., 2009).

Based on the fifth edition of the Indonesian Pharmacopoeia (2014), the tablet weight is considered uniform if there are no more than two tablets weighing more than $5 \%$ of the average tablet weight and none of the tablets weighing more than $10 \%$ of the average tablet weight. Based on the results of Table 6 , the F1 and F2 formulas did not meet the requirements based on Pharmacope V, while the F3, F4, and F5 formulas met the requirements. This is correlated with the results of the flow characteristics of the granules formula F1 and F2, which show poor flow properties when testing the granule characteristics. Formula F3-F5 has better tablet weight uniformity because it uses gelatin excipient which can improve granule flow properties. The good tablet hardness requirements are between 4-8 kP. The requirement for tablet fragility is friability <1\% (Setyawan D., et al., 2020). All F1-F5 formulas gave results that did not meet the requirements due to several factors. The first factor is that black soybean powder is not suitable to be made into tablets by dry granulation method because the binder used is not strong enough to bind between powder particles. The second factor is the possibility of a large oil content in black soybeans so that in the pressing process it causes the oil to come out so that the powder particles become less compact. The oil content in black soybean is on average $19 \%$ or ranges from $6.5-28.7 \%$ depending on the growing area of the plant (Sultan, S.M., et al., 2015).

Research conducted by Yulia et al.,2018 gave similar results, namely the hardness of black soybean tablets made with variations of glidants and lubricants, it turns out that only 1 tablet formula meets the requirements with a yield of $4.12 \pm 0.10 \mathrm{Kg}$. Other formulas in this study on average do not meet the requirements with a range between $0.575-4.12 \mathrm{Kg}$. Another factor is that the excipient greatly affects the hardness and brittleness of the tablets. 
Microcrystalline cellulose filler plays a very important role in the hardness and brittleness of the F1 and F3 tablets, where the tablets were not completely destroyed during the brittleness evaluation process. Unlike the case with the F4 and F5 formulas, the tablets are easily crushed when tested for hardness and brittleness because this formula uses microcrystalline cellulose in smaller quantities than the F1, F2, and F3 formulas. The binder used also affects the hardness and brittleness of the tablets. Formula F2 although the total MCC used is the same as F1 and F3 but it is very easily destroyed when evaluated for its hardness and brittleness. This is because the F2 formula uses a binder, amylum maydis, which is more effective in the form of a binder solution for the wet granulation method. The excipient that is suitable as a binder for the dry granulation method of this study is PVP K30. The requirement for uncoated tablet disintegration is $<15$ minutes (Setyawan, D., et al., 2020). All F1-F5 formulas meet the crush time requirement. This is because the results of the evaluation of the hardness and brittleness of tablets do not eligible so that when the tablets are put into the disintegration media, the tablets will dissolve quickly.

\section{Conclusion}

The formulation and characterization of Detam II black soybean tablets with various excipients and using dry granulation methods have been carried out. Black soybean powder which has poor flow properties and poor compressibility can be molded into tablets by dry granulation method. The excipient used greatly affects the results of the tablets obtained, namely gelatin is able to increase the flow properties of granules, microcrystalline cellulose is the best choice as a filler for black soybean tablets, and PVP K30 is the right binder when using dry granulation / direct compression method. In addition, the researchers recommend making black soybean tablets using the wet granulation method which is expected to improve the flow properties of the granules and increase the hardness of the tablets.

\section{Acknowledgment}

This work was funded by Basic Research Grants No. 26/EI/KPT/2020 from the Ministry of Research and Technology, Republic of Indonesia.

\section{References}

Choung, M.G., et al. 2001. Isolation and determination of anthocyanins in seed coats of black soybean (Glycine max (L.) Merr.). J. Agric. Food Chem., vol. 49, no. 12, pp. 58485851. doi: $10.1021 / \mathrm{jf0} 10550 \mathrm{w}$.

Elisabeth V., P. V. Y. YamLean, and H. S. Supriati. 2018. Formulasi Sediaan Granul Dengan Bahan Pengikat Pati Kulit Pisang Goroho (Musa acuminafe L.) dan pengaruhnya pada sifar fisik granul. Pharmacon, vol. 7, no. 4, pp. 1-11. doi: 10.35799/pha.7.2018.21416.

Fetriyuna. 2015. The potential of darmo black soybean varieties as an alternative of a promising food for future. Int. J. Adv. Sci. Eng. Inf. Technol., vol. 5, no. 1, pp. 44-46. doi: 10.18517/ijaseit.5.1.482.

Ganesan, K. and B. Xu. 2017. A critical review on polyphenols and health benefits of black soybeans. Nutrients: vol. 9, no. 5, pp. 1-17. doi: 10.3390/nu9050455.

Hadisoewignyo L., et al. 2016. Formulation development and optimization of tablet containing combination of salam (Syzygium polyanthum) and sambiloto (andrographis paniculata) ethanolic extracts," Int. J. Pharm. Pharm. Sci., vol. 8, no. 3, pp. 267-273.

Hadisoewignyo L. and A. Fudholi. 2013. Sediaan Solida. Yogyakarta: Pustaka Pelajar.

Hamsinah and Ririn. 2020. Pengembangan Ekstrak Etanol Buah Pepino (Solanum Muricatum 
Aiton) dalam Bentuk Granul Effervescent dengan Variasi Bahan Pengikat. J. Farm. Galen. (Galenika J. Pharmacy). vol. 6, no. 1, pp. 124-131. doi: 10.22487/j24428744.2020.v6.i1.12037.

Jannat E., A. Al Arif, M. Mehdi Hasan, A. Bin Zarziz, H. Ar Rashid, and C. Md Mehdi Hasan. 2016. Granulation techniques \& its updated modules. Pharma Innov. J., vol. 5, no. 10, pp. 134-141.

Kim, J.M., J. S. Kim, H. Yoo, M. G. Choung, and M. K. Sung. 2008. Effects of black soybean Glycine $\max$ (L.) merr. seed coats and its anthocyanidins on colonic inflammation and cell proliferation in vitro and in vivo," J. Agric. Food Chem., vol. 56, no. 18, pp. 8427-8433, 2008, doi: 10.1021/jf801342p.

Kusuma D and E. D. Apriliani. 2018. Evaluasi Fisik Tablet Parasetamol Generik dan Tablet Parasetamol Bermerk Dagang. J. Kefarmasian Akfarindo, vol. 3, no. 1, pp. 1-7.

Kusumo, N.N and S. R. Mita. 2018. Review: Pengaruh Natural Binder Pada Hasil Granulasi Parasetamol. Farmaka, vol. 14, no. 1, pp. 213-221.

Lee, K.L., et al. 2020. Phytochemicals and Antioxidant Activity of Korean Black Soybean (Glycine max L.) Landraces. Antioxidants, vol. 9, no. 3, pp. 1-12. doi: 10.3390/antiox9030213.

Muralidhar P., E. Bhargav, and C. Sowmya. 2016. Novel Techniques of Granulation: a Review. Int. Res. J. Pharm., vol. 7, no. 10, pp. 8-13. doi: 10.7897/22308407.0710114.

Prasanthi S., et al. 2015. Formulation and Evaluation of Sitagliptin Phosphate and Simvastatin Bilayered Tablets. Artic. INFO Abstr. Artic. Hist. Indo Am. J. Pharm. Res., Vol. 2015 no. 8, p. 5.

Rabbani F., P. Husni, and K. Hartono. 2017. "Formulasi Tablet Hisap Ekstrak Kering Daun Sirih Hijau ( Piper betle L )," Farmaka, vol. 15, no. 1, pp. 185-199, 2017.

Rori W.M. and S. Sudewi.2016. Formulasi Dan Evaluasi Sediaan Tablet Ekstrak Daun Gedi Hijau (Abelmoschus manihot) Dengan Metode Granulasi Basah. Pharmacon, vol. 5, no. 2, pp. 243-250. doi: 10.35799/pha.5.2016.12212.

Rowe R.C., P. J. Sheskey, M. E. Quinn, A. P. Association, and P. Press. 2009. Handbook of Pharmaceutical Excipients, vol. 6. Pharmaceutical press: London.

Setyawan D., W. Soeratri, M. N. Nuruddin, D. P. Paramita, and B. Widjaja. 2020. Optimization of Povidone K-30 and Sodium Starch Glycolate on Levofloxacin Tablet by Factorial Design. J. ILMU DASAR, vol. 21, no. 1, p. 35. doi: 10.19184/jid.v21i1.10220.

Shah R.B., M. A. Tawakkul, and M. A. Khan. 2008. Comparative evaluation of flow for pharmaceutical powders and granules. AAPS PharmSciTech, vol. 9, no. 1, pp. 250258. doi: 10.1208/s12249-008-9046-8.

Slavin M., W. Kenworthy, and L. Yu. 2009. Antioxidant properties, phytochemical composition, and antiproliferative activity of Maryland-grown soybeans with colored seed coats. J. Agric. Food Chem., vol. 57, no. 23, pp. 11174-11185, doi: 10.1021/jf902609n.

Sultan S.M., N. Dikshit, and U. J. Vaidya. 2015. Oil content and fatty acid composition of soybean (Glysine max L.) genotypes evaluated under rainfed conditions of Kashmir Himalayas in India. J. Appl. Nat. Sci., vol. 7, no. 2, pp. 910-915. doi: 10.31018/jans.v7i2.706.

Xu B. and S. K. C. Chang. 2008. Antioxidant Capacity of Seed Coat, Dehulled Bean, and Whole Black Soybeans in Relation to Their Distributions of Total Phenolics, Phenolic Acids, Anthocyanins, and Isoflavones. J. Agric. Food Chem, vol. 56, pp. 8365-8373. doi: 10.1021/jf801196d.

Yulia R., A. T. Pradana, S. S. Sie, and F. A. Suri. 2018. Formulation and Physical 
Characteristics of Detam II Soybean (Glycine Max (L.) Merr) Tablet With Various Concentration of Silicon Dioxide and Magnesium Stearate. Asian J. Pharm. Clin. Res., vol. 11, no. 1, p. 283. doi: 10.22159/ajpcr.2017.v11i1.18049.

Zhang, R.F., et al. 2011. Phenolic composition and antioxidant activity in seed coats of 60 chinese black soybean (Glycine max L. Merr.) varieties. J. Agric. Food Chem., vol. 59, no. 11, pp. 5935-5944, 2011, doi: 10.1021/jf201593n. 